\title{
PENINGKATAN KINERJA GURU IPS DAN PPKN DALAM PEMBELAJARAN MELALUI SUPERVISI EDUKATIF KOLABORATIF SECARA PERIODIK DI SMP
}

\author{
Khatib \\ SMP Negeri 2 Sungai Melayu Rayak \\ Email:khatibsmpn2@gmail.com
}

\begin{abstract}
Abstrak
Seorang guru harus selalu meningkatkan kemampuan profesionalnya, pengetahuan, sikap dan keterampilannya secara terus-menerus sesuai perkembangan ilmu pengetahuan dan teknologi termasuk paradigma baru pendidikan. Menurut Dirjen Pendidikan Dasar dan Menengah Departemen Pendidikan Nasional (2004:2) seorang guru harus memenuhi tiga standar kompetensi diantaranya: (1).Kompetensi pengelolaan pembelajaran dan wawasan pendidikan.(2)Kompetensi Akademik/Vokasional sesuai materi pembelajaran.(3) Pengembangan profesi.Ketiga kompetensi tersebut bertujuan agar guru dan pembelajaran bermutu yang akhirnya meningkatkan mutu pendidikan Indonesia. Untuk mencapai ketiga kompetensi tersebut, sekolah harus melakukan pembinaan terhadap guru baik melalui workshop, PKG, diskusi, dan supervisi edukatif. Hal itu harus dilakukan secara periodik agar kinerja dan wawasan guru bertambah. Penelitian ini merupakan penelitian tindakan, maka pelaksanakan ini dilaksanakan secarasiklus. Setiap siklusnya selalu ada persiapan tindakan, pelaksanaan tindakan, pemantauan evaluasi, dan refleksi.Simpulan dari penelitian ini adalah pelaksanaan supervisi edukatif kolaboratif secara periodik dapat meningkatkan kinerja guru dalam melaksanakan pembelajaran, dapat meningkatkan kinerja guru dalam menilai prestasi belajar siswa dan dapat meningkatkan kinerja guru dalam melaksanakan tindak lanjut hasil prestasi belajar siswa.
\end{abstract}

\section{Kata Kunci: Peningkatan Kinerja Guru, Pembelajaran Supervisi Edukatif Kolaboratif, Periodik.}

\section{PENDAHULUAN}

Dalam rangka meningkatkan mutu pendidikan di Indonesia, pemerintah telah menetapkan Undang-Undang Sistem Pendidikan. Undang-Undang tersebut memuat dua puluh dua bab, tujuh puluh tujuh pasal dan penjelasannya. Undang-undang Sistem Pendidikan (2003:37) menjelaskan bahwa setiap pembaharuan sistem pendidikan nasional harus memperbarui visi, misi dan strategi pembangunan pendidikan nasional.
Seorang guru harus selalu meningkatkan kemampuan profesionalnya, pengetahuan, sikap dan keterampilannya secara terusmenerus sesuai perkembangan ilmu pengetahuan dan teknologi termasuk paradigma baru pendidikan. Menurut Dirjen Pendidikan Dasar dan Menengah Departemen Pendidikan Nasional (2004:2) seorang guru harus memenuhi tiga standar kompetensi diantaranya: (1) Kompetensi pengelolaan pembelajaran dan wawasan pendidikan, (2) Kompetensi Akademik/Vokasional sesuai 
materi pembelajaran, (3) Pengembangan profesi. Ketiga kompetensi tersebut bertujuan agar guru dan pembelajaran bermutu yang akhirnya meningkatkan mutu pendidikan Indonesia. Untuk mencapai tiga kompetensi tersebut, sekolah harus melaksanakan pembinaan terhadap guru baik melalui workshop, PKG, diskusi dan supervisi edukatif. Hal itu harus dilakukan secara periodik agar kinerja dan wawasan guru bertambah sebab berdasarkan diskusi yang dilakukan guru di SMP Negeri 2 Sungai Melayu Rayak, rendahnya kinerja dan wawasan guru diakibatkan (1) rendahnya kesadaran guru untuk belajar, (2) kurangnya kesempatan guru mengikuti pelatihan, baik secara regional maupun nasional, (3) kurang efektifnya PKG, (4) supervisi pendidikan yang bertujuan memperbaiki proses pembelajaran cenderung menitik beratkan pada aspek administrasi.

Untuk memperbaiki kinerja dan wawasan guru dalam pembelajaran di SMP Negeri 2 Sungai Melayu Rayak, sekolah melaksanakan penelitian tindakan yang berkaitan dengan permasalahan di atas. Karena keterbatasan peneliti, maka penelitian ini hanya difokuskan pada supervisi edukatif saja sehingga judul penelitian tindakan tersebut adalah "Peningkatan Kinerja Guru IPS dan PPKN dalam Pembelajaran di Kelas Melalui Supervisi Edukatif Kolaboratif secara Periodik“ di SMP Negeri 2 Sungai Melayu Rayak.

Sesuai permasalahan diatas, penelitian ini bertujuan untuk: (1) mendeskripsikan langkah-langkah supervisi edukatif kolaboratif secara periodik dalam melaksanakan pembelajaran. (2) mendeskripsikan langkah-langkah supervisi edukatif kolaboratif secara periodik dalam menilai prestasi belajar. (3) mendeskripsikan langkah-langkah supervisi edukatif kolaboratif secara periodik dalam melaksanakan tindak lanjut penilaian prestasi belajar siswa. (4) mendeskripsikan langkah- langkah supervisi edukatif kolaboratif secara periodik dalam menyusun rencana pembelajaran.

Adapun maksud penulis mengadakan penelitian ini diharapkan dapat berguna untuk: (1) mengembangkan potensi yang dimiliki peserta didik sehingga dapat meningkatkan hasil belajarnya. (2) meningkatkan wawasan guru sehingga termotivasi untuk meningkatkan kinerjanya.

Kompetensi merupakan spesifikasi dari kemampuan, keterampilandan sikap yang dimiliki seseorang serta penerapannya di dalam pekerjaan, sesuai dengan standar kinerja yang dibutuhkan oleh lapangan (DirjenDikdasmen, 2004:4). Berdasarkan pendapat tersebut seorang yang bekerja sebagai guru, yang pekerjaan itu menurut Undang-Undang Guru tahun 2006 merupakan pekerjaan profesional maka guru harus memenuhi standar-standar minimal yang dibutuhkan oleh Depdiknas.

Komponen-komponen stantar kompetensi guru antara lain: (1) Komponen Kompetensi Pengelolaan Pembelajaran dan Wawasan Kependidikan, (2) Komponen Kompetensi Akademik/Vokasional sesuaimateri pembelajaran, (3) Pengembangan profesi. Selain ketiga komponen tersebut, seorang guru harus memiliki sikap dan kepribadian yang positif, di mana sikap dan kepribadian tersebut senantiasa melekat pada setiap komponen yang menunjang profesi guru.

Kompetensi akademik ini berkaitan dengan penguasaan materi pelajaran yang akan dipelajari/dipahami/dikuasai siswa. Guru harus menguasai materi yang akan diajarkan. Oleh sebab itu, kompetensi bidang akademik ini berkaitan dengan penguasaan keterampilan sesuai dengan materi pembelajaran. Menurut Dirjen Dikmenum (2004:14) hanya ada satu kompetensi di bidang ini, yaitu: menguasai keilmuan dan keterampilan sesuai materi pembelajaran, dengan indikator: Menguasai materi pembelajaran di bidangnya. 
Menurut Rivai (2004:309), kinerja guru adalah: perilaku nyata yang ditampilkan oleh guru sebagai prestasi kerja berdasarkan standar yang ditetapkan dan sesuai dengan perannya di sekolah.Peran guru yang dimaksud adalah berkaitan dengan peran guru dalam proses pembelajaran. Guru merupakan faktor penentu yang sangat dominan dalam pendidikan pada umumnya, karena guru memegang peranan dalam proses pembelajaran, dimana proses pembelajaran merupakan inti dari proses pendidikan secara keseluruhan. Guru merupakan perencana, pelaksana sekaligus sebagai evaluator pembelajaran di kelas( Gunawan dalam Ondi Saondi, 2005:3 ).

Menurut Pidarta guru sebagai pekerja merupakan pribadi yang berkembang harus memiliki kemampuan yang meliputi unjuk kerja, penguasaan materi, penguasaan profesional keguruan dan 14 pendidikan, penguasaan cara-cara menyesuaikan diri melaksanakan tugasnya. ( Pidarta dalam Ondi Saondi 2010: 4). Hal ini sesuai dengan yang tertuang dalam Undang-undang No.20 tahun 2003 tentang Sistem Pendidikan Nasional bahwa pendidik dan tenaga kependidikan berkewajiban (1) menciptakan suasana pendidikan yang bermakna, menyenangkan, kreatif, dinamis dan dialogis, (2) mempunyai komitmen secara profesional untuk meningkatkan mutu pendidikan dan (3) memberi teladan dan menjaga nama baik lembaga, profesi dan kedudukan sesuai dengan kepercayaan yang diberikan kepadanya. Berkenaan dengan standar kinerja guru Sahertian dalam Kusmianto (1997: 49) bahwa, standar kinerja guru itu berhubungan dengan kualitas guru dalam menjalankan tugasnya seperti: (1) bekerja dengan siswa secara individual, (2) persiapan dan perencanaan pembelajaran, pendayagunaan media pembelajaran, (4) melibatkan siswa dalam berbagai pengalaman belajar, dan (5) kepemimpinan yang aktif dari guru. Kinerja guru mempunyai spesifikasi tertentu. Kinerja guru dapat dilihat dan diukur berdasarkan spesifikasi/kriteria kompetensi yang harus dimiliki oleh setiap guru. Berkaitan dengan kinerja guru, wujud perilaku yang dimaksud adalah kegiatan guru dalam proses pembelajaran yaitu bagaimana kemampuan seorang guru dalam merencanakan pembelajaran, melaksanakan kegiatan pembelajaran, dan menilai hasil belajar.

\section{METODE PENELITIAN}

Penelitian ini dilaksanakan di SMP Negeri 2 Sungai Melayu RayakKecamatan Sungai Melayu Rayak Kabupaten Ketapang pada tahun pelajaran 2018/2019.Pada tahun itu banyak hasil penelitian yang kurang mengarah pada peningkatan mutu pendidikan. Peneliti mengambil tempat penelitian di SMP Negeri 2 Sungai MelayuRayak Kecamatan Sungai Melayu Rayak Kabupaten Ketapang karena guru-guru di SMP Negeri 2 Sungai Melayu Rayak ada yang GTT, GK, PNS, dan ijazahnya pun beragam, yakni ada yang berijazah diploma, sarjana, dan pascasarjana. Waktu penelitian adalah pada tahun pelajaran 2018/2019. Selama penelitian tersebut peneliti mengumpulkan data awal, menyusun program supervisi, pelaksanaan supervisi, analisis, dan tindak lanjut. Penelitian ini merupakan penelitian tindakan makapelaksanakan ini dilaksanakan secara siklus. Pelaksanaannya selama duasiklus.Siklus-siklus itu merupakan rangkaian yang saling berkelanjutan, maksudnya siklus kedua merupakan kelanjutan dari siklus pertama.Setiap siklusnya selalu ada persiapan tindakan, pelaksanaan tindakan, pemantauan dan evaluasi, dan refleksi.Gambaran penelitan tindakan itu sebagai berikut.Gambaran Pelaksanaan Siklus I terdiri dari : (a) Persiapan Tindakan. (b) Pelaksanaan Tindakan. (c) Pemantauan dan Evaluasi, dan (d) Refleksi.

Teknik pengumpulan data pada penelitian ini terdiri atas empat kegiatan pokok yakni pengumpulan data awal, data 
hasil analisis setiap akhir siklus, serta tanggapan lain dari guru terhadap pelaksanaan supervisi edukatif model kolaboratif. Data yang telah dikumpulkan dianalisis dengan menggunakan analisis kualitatif dan kuantitatif.Analisis kualitatif digunakan untuk menjelaskan perubahan perilaku guru dalam pembelajaran dan perilaku data yang telah dikumpulkan dianalisis dengan menggunakan analisis kualitatif dan kuantitatif.Analisis kualitatif digunakan untuk menjelaskan perubahan perilaku guru dalam pembelajaran dan perilaku peneliti dalam melakukan supervisi guru. Adapun analisis kuantitatif digunakan untuk mengetahui keberhasilan guru dan siswa berdasarkan standar kompetensi guru yang telah ditetapkan.

\section{HASIL DAN PEMBAHASAN PENELITIAN}

Berdasarkan pemantauan selama persiapan, pelaksanaan, dan tindak lanjut penelitian tindakan ini diperoleh berbagai data baik dari guru yang sedang melaksanakan proses belajar mengajar, siswa yang belajar, Peneliti yang sedang melaksanakan supervisisnya. Gambaran yang merupakan hasil dan temuan penelitian sebagai berikut.

\section{Siklus 1}

Setelah dilaksanakan diskusi dengan guru kelas maka peneliti menulis hasil refleksi sebagai berikut: (1) Mendeskripsikan tujuan pembelajaran dua Guru dengan presentasi 83 $\%$, berdasarkan data tersebut kegiatan guru sudah sangat baik. Kegiatan seperti itu dipertahankan, tetapi ada beberapa guru yang perlu dimotivasi. (2) Menentukan materi sesuai dengan kompetensi yang telah ditentukan sebanyak dua guru dengan presentasi $83 \%$, berdasarkandata itukegiatan guru tersebut dipertahankan.

Mengorganisasikan materi berdasarkan urutan dan kelompok sebanyak 2 Guru dengan presentasi $66,4 \%$. Pada bagian ini guru perlu diberi bimbingan lagi tentang bagaimana mengorganisasikan matari berdasarkan urutannya. Guru diberi contoh pembelajaran berdasarkan pembelajaran CTL, CL. (4) Mengalokasikan waktu sebanyak 2 Guru dengan presentasi $100 \%$. Kegiatan pada bagian ini dipertahankan yakni menentukan alokasi waktu melalui workshop guru mata pelajaran di sekolah dengan dipandu peneliti. (5) Menentukan metode pembelajaran yang sesuai sebanyak 2 guru dengan presentasi 49,8 $\%$, berdasarkan catatan dan hasi pelaksanaan ternyata pada bagian ini guru perlu diberi bimbingan, pengarahan dengan cara berdiskusi dengan peneliti untuk menetapkan metode yang berkaitan dengan kontekstual. (6) Merancang prosedur pembelajaran sebanyak 2 Guru dengan presentasi 66,4\%. Pada penentuan prosedur sangat berkaitan dengan metode pembelajaran.Oleh sebab itu, perlu ada perbaikan di bidang ini.

Guru masih terpancang dengan prosedur-prosedur yang sifatnya mengancam siswa jika kurang mampu atau melanggar pembelajaran. (7) Menentukan media pembelajaran/peralatan praktikum (dan bahan) yang akan digunakan sebanyak 2 Guru dengan presentasi $66,4 \%$. Guru pada bagian ini masih terfokus pada media yang dibeli atau dibuat oleh perusahaan padahal di sekitar kelas banyak media alami yang bisa digunakan sebagai media. Bagian ini, masih perlu diperbaiki. (8) Menentukan sumber belajar yang sesuai (berupa buku, modul, program komputer dan sejenisnya) sebanyak 2 Guru dengan presentasi $83 \%$. (9) Menentukan teknik penilaian sebanyak 2 guru dengan presentasi $49,8 \%$. Teknik-teknik yang dibuat guru dalam menyusun penilaian masih kurang beragam. Guru masih terfokus pada teknik tradisional yakni penilaian hasil saja, padahal kita juga perlu penilaian proses.

Hasil refleksi pada bagian pelaksanaan supervisi dan setelah diadakan diskusi dengan guru kelas sebagai berikut: (1) Membuka pelajaran dengan metode yang sesuai. Guru rata-rata sudah mampu membuka pelajaran 
dengan metode yang tepat. Guru yang dianggap mampu membuka pelajaran dengan tepat sebanyak 2 orang atau dengan persentasi $83 \%$. Berdasarkan persentasi di atas, guru perlu mempertahankan cara tersebut. Adapun satu guru yang belum sesuai perlu diajak diskusi bersama dengan peneliti. (2) Melaksanakan penilaian berjumlah 2 Guru dengan persentasi $83 \%$ masih ada guru yang membiarkan siswanya membuka buku dalam ulangan tersebut. Hal seperti ini akan merugikan anak. Bahkan penilaian itu tidak bisa digunakan untuk mengukur kemampuan siswa. Guru seperti ini perlu diberi bimbingan secara khusus tentang pentingnya penilaian. (3) Memeriksa jawaban/ memberikan skor tes hasil belajar berdasarkan indikator/kriteria unjuk kerja yang telah ditentukan berjumlah 2 Guru dengan persentasi $66,4 \%$. Guru yang belum mampu memberikan skor ialah guru yang belum pernah mengikuti pelatihan, skor dianggap sama dengan bobot. Untuk mengatasi seperti itu, guru-guru tersebut diikutkan MGMP kabupaten atau diberi bimbingan secara khusus. (4) Mengolah hasil penilaian berjumlah 2 guru dengan persentasi $66,4 \%$. guru yang belum mampu mengolah nilai sebagian besar sama dengan guru yang tidak paham terhadap penyekoran pembobotan nilai.

\section{Siklus II}

Siklus II dilaksanakan berdasarkan temuan siklus I. Bagian yang sudah baik dipertahankan, sedangkan bagian yang persentasi keberhasilannya kecil diperbaiki pada siklus II ini.Berdasarkan refleksi dan pelaksanaan tindak lanjut siklus I. (1) Mendeskripsikan tujuan pembelajaran 6 Guru dengan presentasi $100 \%$, berdasarkan data tersebut sudah mampu mendeskripsikan tujuan pembelajaran. Untuk itu, model seperti ini tetap dipertahankan. (2) menentukan materi sesuai dengan kompetensi yang telah ditentukan sebanyak 6 Guru dengan presentasi
$100 \%$. Ternyata guru sudah mampu menentukan materi pembelajaran yang sesuai dengan kompetensinya Guru lebih mudah menjalankan tugasnya jika supervise edukatif dilakukan secara kolaboratif dengan PenelitiPembahasan

Pembahasan didasarkan pada teori-teori yang sudah ada, baik berdasarkan pada referensi mapun dari ucapan ahli di bidang penelitian ini.Adapun pembahasan hasil penelitian ini sebagai berikut: Temuan

pertama, kinerja guru meningkat dalam membuat perencanaan pembelajaran. Hal ini terjadi karena adanya kerja sama antara guru kelas yang satu dengan lainnya serta diberi pengarahan oleh peneliti. Langkah-langkah yang dapat meningkatkan kinerja guru dalam membuat persiapan pembelajaran adalah: (1) Peneliti memberikan format supervisi dan jadwal supervisi pada awal tahun pelajaran atau awal semester. Pelaksanaan supervisi tidak hanya dilakukan sekali, (2) Peneliti selalu menanyakan perkembangan pembuatan perangkat pembelajaran (mengingatkan betapa pentingnya perangkat pembelajaran), (3) satu minggu sebelum pelaksanaan supervisi perangkat pembelajaran, Peneliti menanyakan format penilaian, jika format yang diberikan ada awal tahun pelajaran tersebut hilang, maka guru yang bersangkutan disuruh memfotokopi arsip sekolah. Jika di sekolah masih banyak format seperti itu maka guru tersebut diberi kembali. Bersamaan dengan memberi/menanyakan format, Peneliti meminta pengumpulan perangkat pembelajaran yang sudah dibuatnya untuk untuk diteliti kelebihan dan kekurangannya, (4) Peneliti memberikan catatan-catatan khusus pada lembaran untuk diberikan kepada guru yang akan disupervisi tersebut. (5) Peneliti dalam menilai perangkat pembelajaran penuh perhatian dan tidak mencerminkan sebagai penilai. Peneliti bertindak sebagai kolaborasi. Peneliti membimbing, mengarahkan guru yang belum bisa, tetapi Peneliti juga menerima argumen 
guru yang positif. Dengan adanya itu, terciptalah hubungan yang akrap antara guru dan Peneliti. Tentu saja ini akan membawa nilai positif dalam pelaksanaan pembelajaran.

Temuan kedua, kinerja guru meningkat dalam melaksanakan pembelajaran.Dalam penelitian tindakan ini ternyata dari 6 guru hampir semuanya mampu melaksanakan pembelajaran dengan baik.Hal ini terbukti dari hasil supervisi. Langkah-langkah yang dilakukan untuk meningkatkan pelaksanaan pembelajaran berdasarkan penelitian tindakan ini adalah: (1) Peneliti yang mengamati guru mengajar tidak sebagai penilai tetapi sebagai rekan bekerja yang siap membantu guru tersebut, (2) Selama pelaksaaan supervisi di di kelas guru tidak menganggap peneliti sebagai penilai karena sebelum pelaksanaan supervisi guru dan Peneliti telah berdiskusi permasalahan-permasalahan yang ada dalam pembelajaran tersebut,(3) Peneliti mencatat semua peristiwa yang terjadi di dalam pembelajaran baik yang positif maupun yang negatif, (4) Peneliti selalu memberi contoh pembelajaran yang berorientasi pada Modern Learning. (5) Jika ada guru yang pembelajarannya kurang jelas tujuan, penyajian, umpan balik, Peneliti memberikan contoh bagaimana menjelaskan tujuan, menyajikan, memberi umpan balik kepada guru tersebut.(6) Setelah guru diberi contoh pembelajaran modern, Peneliti setiap dua atau tiga minggu mengunjungi atau mengikuti guru tersebut dalam proses pembelajaran.

Temuan ketiga, kinerja guru meningkat dalam menilai prestasi belajar siswa. Pada penelitian tindakan yang dilakukan di SD Negeri 1 Gunungtumpeng Kecamatan Karangrayung ini ternyata pelaksanaan supervisi edukatif kolaboratif secara periodik memberikan dampak positif terhadap guru dalam menyusun soal/perangkat penilaian, melaksanakan, memeriksa, menilai, mengolah,menganalisis, menyimpulkan, menyusun laporan dan memperbaiki soal. Sebelum diadakan supervisi edukatif secara kolaboratif, guru banyak yang mengalami kesulitan dalam melaksankan penilaian. Langkah-langkah yang dilakukan dalam supervisi edukatif kolaboratif secara periodik yang dapat meningkatkan kinerja guru adalah (1) Peneliti berdiskusi dengan guru dalam pembuatan perangkat penilaian sebelum dilaksanakan supervisi, (2) Guru melaksanakan penilaian sesuai dengan aturan yang telah ditetapkan bersama Peneliti yang sebagai kolaboratif dalam pembelajaran, (3) Guru membuat kriteria penilaian yang berkaitan dengan penskoran, pembobotan, dan pengolahan nilai, yang sebelum pelaksanaan supervisi didiskusikan dengan peneliti, (4) Guru menganalisis hasil penilaian dan melaorkannya kepada urusan kurikulum.

Temuan keempat, Kinerja guru meningkat dalam melaksanakan tindak lanjut hasil penilaian prestasi belajar peserta didik. Langkah-langkah yang dapat meningkatkan kinerja guru dalam supervisi edukatif kolaboratif adalah: (1) Peneliti dan guru bersama-sama membuat program tindak lanjut hasil penilaian, (2) Peneliti memberi contoh pelaksanaan tindak lanjut, yang akhirnya dilanjutkan oleh guru dalam pelaksanaan yang sebenarnya, (3) Peneliti mengajak diskusi pada guru yang telah membuat, melaksanakan, dan menganalis program tindak lanjut.

Temuan kelima, Kinerja guru meningkat dalam menyusun program pembelajaran, melaksanakan pembelajaran, menilai prestasi belajar, dan melaksanakan tindak lanjut hasil prestasi belajar siswa.

\section{SIMPULAN DAN SARAN Simpulan}

Berdasarkan temuan hasil penelitian ada empat hal yang dikemukakan dalam penelitian tindakan ini : (1)Pelaksanaan supervisi edukatif kolaboratif secara periodik dapat meningkatkan kinerja guru dalam menyusun rencana pebelajaran. (2) Pelaksanaan supervisi edukatif kolaboratif secara periodik dapat 
meningkatkan kinerja guru dalam menyusun rencana pebelajaran. (3) Pelaksanaan supervisi edukatif kolaboratif secara periodik dapat meningkatkan kinerja guru dalam menilai prestasi belajar siswa. (4) Pelaksanaan supervisi edukatif kolaboratif secara periodik dapat meningkatkan kinerja guru dalam melaksanakan tindak lanjut hasil penilaian prestasi belajar siswa.

\section{Saran}

Berdasarkan temuan-temuan penelitian tindakan ini, ada beberapa saran yang perlu disampaikan kepada pengambil kebijakan sekolah, di antaranya adalah: (1) Supervisi terhadap semua guru perlu dilakukan secara periodik dan ditetapkan pada awal tahun pelajaran (pada saat pembagian tugas). (2) Supervisi edukatif ternyata membawa peningkatan kinerja guru dan hasilbelajar siswa jika dilaksanakan secara kolaboratif. (3) Supervisi edukatif kolaboratif akan bermakna jika Penelitinya adalah teman sejawat yang sudah mampu pada mata pelajaran yang bersangkutan. (4) Perlu memberi kesempatan pada guru-guru yang dianggap sudah mampu mensupervisi guru lain.

\section{DAFTAR PUSTAKA}

Afifudin.2007. Kinerja Guru Madrasah Aliyah, Studi tentang Pengaruh Kepemimpinan Kepala Sekolah, Supervisi Akademik, dan Budaya Organisasi terhadap Kinerja Guru Madrasah Aliyah Negeri di Jawa Barat. Bandung: Universitas Islam Negeri Bandung. Disertasi: tidak diterbitkan

Arikunto, Suharsimi. 2006. Manajemen Pendidikan. Yogyakarta: Aditya Media 2010. Prosedur Penelitian suatu Pendekatan Praktik. Yogyakarta: PT. Rineka Cipta

Bernardin, H.J. and Russel, J.E.A. 1997. Human Resource Management 2nd Edition-An Experential Approach. Singapore: McGraw-Hill 